\title{
維持透析における $1,25(\mathrm{OH})_{2} \mathrm{D}_{3}$ パルス療法の 貪食細胞機能に及ぼす影響について
}

\author{
徳田倫章明利浩行加野資典熊澤淨一* \\ 加野病院泌尿器科 九州大学泌尿器科*
}

key words：血液透析, calcitriol, 活性酸素産生能, 貪食能, HLA-DR 抗原

〈要旨〉

維持透析患者 12 名において, 末梢血中の CD14 陽性単球の HLA-DR (DR) 抗原の発現量ならびに好中球の貪食 能と phorbol myristate acetate (PMA) 刺激による活性酸素産生能 (SOP) をフローサイトメトリー法で測定し, 正常対照群 9 名と比較検討した。 また活性型ビタミン $\mathrm{D}_{3}$, calcitriol, $1,25(\mathrm{OH})_{2} \mathrm{D}_{3}\left(1,25 \mathrm{D}_{3}\right)$ パルス療法前後でこ れらの機能の変化を検討した。透析患者では, 正常対照群に比し単球の DR 抗原の発現量 $(p<0.05)$ ならびに好 中球の PMA 刺激による SOP ( $\mathrm{p}<0.001)$ は有意に増加していたが, 好中球の貪食能は低下傾向にあった. 透析患 者の $1,25 D_{3}$ の血中濃度は, ビタミンD製剤の休薬後は未検出レベルと低下していたが, $1,25 \mathrm{D}_{3}$ パルス療法の 5 $\mu \mathrm{g}$ 経口投与後 4 時間以内に $200 \mathrm{pg} / \mathrm{m} l$ を超える血中濃度が認められた。 $1,25 \mathrm{D}_{3}$ 投与により, 72 時間後の単球の DR 抗原の発現は有意に抑制され $(\mathrm{p}<0.001)$, また好中球の SOP は増強される傾向を示した。しかし好中球の貪 食能には一定の作用は認められなかった。

$1,25 \mathrm{D}_{3}$ が貪食細胞の種々の機能に対して明らかな作用をもつことより, $1,25 \mathrm{D}_{3}$ が生体防御機構に対しても何ら かの役割を果たしており，腎不全における免疫不全状態に関与している可能性が示唆された。

\section{Vitamin $D_{3}$ therapy modulates phagocyte functions in patients with renal failure}

Noriaki Tokuda, Hiroyuki Meiri, Motonori Kano, Joichi Kumazawa*

Department of Urology, Kano Hospital ; Department of Urology, Faculty of Medicine, Kyushu University*

Calcitriol, $1,25(\mathrm{OH})_{2} \mathrm{D}_{3}\left(1,25 \mathrm{D}_{3}\right)$ modulates several neutrophil and monocyte functions in vitro, including phorbol myristate acetate (PMA)-induced superoxide production (SOP), HLA-DR (DR) expression, and phagocytic activity. We therefore investigated SOP and phagocytic activity using peripheral blood neutrophils and DR expression using peripheral blood $\mathrm{CD} 14^{+}$monocytes from 12 patients on periodic hemodialysis (HD), before and after oral treatment with $1,25 \mathrm{D}_{3}(5 \mu \mathrm{g}$ twice a week). Both SOP by neutrophils and DR expression by monocytes were significantly higher in HD patients than in the normal control group $(p<0.001$ and $p<$ 0.05 , respectively). Phagocytic activity by neutrophils in the HD patients was slightly reduced but not significantly different from that in the normal control group.

$1,25 \mathrm{D}_{3}$ therapy resulted in a marked increase in plasma $1,25 \mathrm{D}_{3}$ level $(>200 \mathrm{pg} / \mathrm{ml})$ within 4 hours after treatment. After 3 days of treatment, DR expression by monocytes was significantly reduced $(p<0.01)$. Treatment slightly enhanced PMA-induced SOP, but the effect was not significant. Phagocytic activity by peripheral blood neutrophils was not significantly affected by treatment. These findings suggest that $1,25 D_{3}$ has a role in the regulation of monocytic function in HD patients.

徳田 倫章 加野病院泌尿器科 $\overline{\mathrm{T}} 811-31$ 粕屋郡古賀町花見南 1-2-15 (092-944-1212) 〔受付: 平成 6 年 8 月 17 日, 受理: 平成 6 年 10 月 17 日〕 


\section{緒言}

末期腎不全は透析療法の進歩に伴い長期生存が 可能となっている。しかしながら解決されるべき 問題の 1 つに免疫不全状態の存在があり, 結核な どに対する易感染性，悪性腫瘍の発生率の増加な どを引き起こすと考えられている11.一方, 未期腎 不全は腎に打けるビタミン $\mathrm{D}_{3} 1 \alpha$-OHase 活性が 低下して扔り，慢性の活性型ビタミン $\mathrm{D}_{3}, \quad 1,25$ $(\mathrm{OH})_{2} \mathrm{D}_{3}\left(1,25 \mathrm{D}_{3}\right)$ 欠乏状態でもある。

近年, $1,25 \mathrm{D}_{3}$ の生体防御機構における重要性に 注目が集まっている.先天性 $1,25 \mathrm{D}_{3}$ 欠乏症である くる病や実験的に作られた $1,25 \mathrm{D}_{3}$ 欠乏マウスに は種々の免疫異常が報告されている, $1,25 \mathrm{D}_{3}$ は in vitro においてリンパ球，好中球さ らに単球マクロファージ系の細胞の種々の機能に 直接影響を与えることも報告されている ${ }^{4 \sim 8)}$.

しかしながら末期腎不全に打ける慢性の 1,25 $\mathrm{D}_{3}$ 欠乏状態と免疫不全状態との相互関係につい ては,十分な解析がなされているとはいいがたい. 今回, $1,25 \mathrm{D}_{3}$ パルス療法前後で, 維持透析患者の 好中球の活性酸素産生能 (SOP) と貪食能ならび に単球の HLA-DR (DR) 抗原の発現量について 検討した。

\section{対象}

原疾患が糖尿病でない透析患者 12 名〔男 7 名, 女 5 名, 平均年齢 $51.8 \pm 13.1$ (36 67 歳), 平均 透析歷 $26 \pm 19.2$ 加 ( $6 \sim 62$ 加) ) を対象とし, 透析は週 3 回, 透析時間 $4 \sim 5$ 時間, 血液流量 150 $\sim 200 \mathrm{ml} / \mathrm{min}$, 透析液流量 $500 \mathrm{ml} / \mathrm{min}$ にて施行 している。これらの患者に 3 週間以上のビタミン $\mathrm{D}_{3}$ 製剤の休薬期間ののち $1,25 \mathrm{D}_{3}$ パルス療法を施 行した。正常対照として 9 名〔男 5 名, 女 4 名, 平均年齢 $47.6 \pm 8.5$ (36〜 60 歳) ]を用いた。透析 患者群と正常対照群とで性別，年齢で有意差は認 めない。なお，パルス療法施行期間中に使用ダイ アライザーならびに透析条件の変更はなかった。

\section{方法}

1. $1,25 \mathrm{D}_{3}$ パルス療法

週 2 回（金，月）透析終了時に $1,25 \mathrm{D}_{3}$ を $5 \mu \mathrm{g}$ 経口投与し，第 2 週より $4 \mu \mathrm{g}$ とし，以後は患者 により増減した。
2. $1,25 \mathrm{D}_{3}$ 血中濃度の測定

$1,25 \mathrm{D}_{3}$ パルス療法直前 ( 0 時間), $1,25 \mathrm{D}_{3}$ 初回 量 $5 \mu \mathrm{g}$ 経口投与 4 時間後, 24 時間後, 3 日後の 透析直前 (68 時間後)，2 回目 $5 \mu \mathrm{g}$ 経口投与 4 時 間後 (76 時間後)，96 時間後に HPLC 法を用いて 測定した。

3. CD14 陽性単球の DR 発現量ならびに好中 球の SOP と貫食能の測定

$1,25 \mathrm{D}_{3} 5 \mu \mathrm{g}$ 投与前後 (金〜月) で透析直前に採 血し，末梢血 CD14 陽性単球の DR 発現量ならび に好中球の貪食能と SOP を検討した。単球の DR 発現量の測定は, FITC 標識抗 CD14 抗体 (Leu$\mathrm{M} 3$, マウス $\mathrm{IgG}_{2} \mathrm{~b}$, Becton dickinson immunocytometry systems）ならびに PE 標識抗 HLA-DR 抗体 (OKDR, マウス $\operatorname{IgG}_{2}$ a, Ortho diagnostic systems）を $4{ }^{\circ} \mathrm{C} ， 20$ 分間作用させ単球の特異的 マーカーである CD14 陽性分画の細胞の DR 発現 量を 2 カラーフローサイトメトリー法にて解析し た。なお，発現量は平均蛍光強度で表した(MFI； 細胞 1 個当たりの DR 発現量を反映).

SOP 測定は, Bassらの方法に準じ9)，ヘパリン 加静脈血 $0.1 \mathrm{~m} l$ に $5 \mu \mathrm{M}$ の dichlorofluorescin diacetate (DCFH-DA) $2 \mathrm{~m} l$ を加え, $37^{\circ} \mathrm{C} 15$ 分 間振盪加温する。その後ただちに氷水中に冷却し ながら反応を止め, EDTA $0.5 \mathrm{~m} l$ を加える.さら に $25 \mu \mathrm{g} / \mathrm{m} l$ の phorbol myristate acetate (PMA) を添加し, 再び $37^{\circ} \mathrm{C} 20$ 分間振盪加温した のち, フローサイトメトリー法にて解析し平均蛍 光強度で表した（細胞 1 個当たりの SOP 反 映). 好中球の貪食能に関しては，へパリン加静脈 血 $0.1 \mathrm{~m} l$ に径 $2 \mu \mathrm{m}$ の FITC 蛍光標識された carboxyl microsphere (Polyscience Inc.) $5 \times$ $10^{6}$ 個加え, $37^{\circ} \mathrm{C} て ゙ 25$ 分間振盪加温する。その後た だちに氷水中に冷却しながら反応を止め, フロー サイトメトリー法にて好中球分画を解析した。

正常との比較ならびに $1,25 \mathrm{D}_{3}$ 投与前後の比較 は正常対照群の平均值を 100 として解析した。

4. 統計処理

統計処理の方法としては，対応のある場合は Wilcoxon signed rank test を，対応のない場合 は Mann-Whitney $U$ test を用い, 有意水準 $5 \%$ 


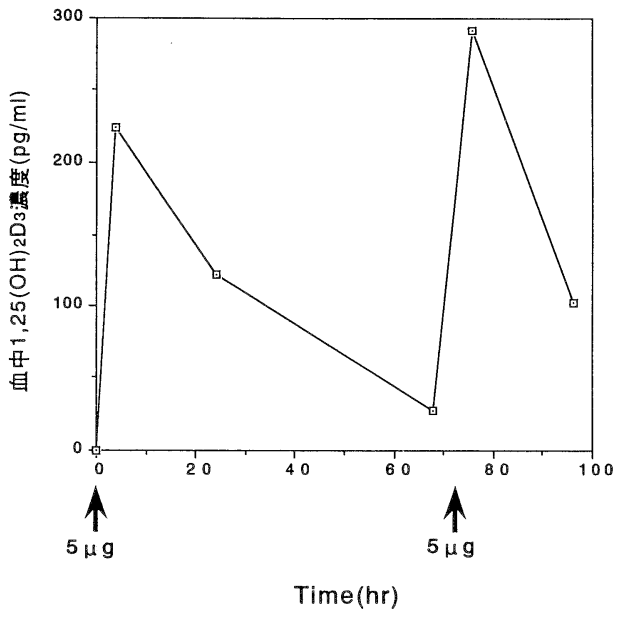

図 1 パルス療法前後の血中 $1,25(\mathrm{OH})_{2} \mathrm{D}_{3}$ 濃度

をもって有意差ありとした。

\section{結果}

1. $1,25 \mathrm{D}_{3}$ の血中濃度の変化

パルス療法前に扔いては, 血中の $1,25 \mathrm{D}_{3}$ レベル は未検出レベルと低下していた。 $1,25 \mathrm{D}_{3}$ 経口内服 後, 血中 $1,25 \mathrm{D}_{3}$ レベルは急速に上昇し 4 時間以内 に $200 \mathrm{pg} / \mathrm{m} l$ に達し, 以後下降した. 3 日後の経 口内服後 $300 \mathrm{pg} / \mathrm{m} l$ 近くまで再上昇した（図 1 ).

2. パルス療法前後における末梢血 CD14 陽性 単球の HLA-DR 抗原の発現量の変化

CD14 抗原は単球マクロファージ系の細胞表面 に特異的に発現される抗原で10), 未梢血中のこの 抗原をもった単球と考元られる細胞の DR 抗原 の発現の解析を行った(図 2 )。単球分画における CD14 抗原の発現に関しては, 正常対照群と透析 患者群とも約 $80 \%$ の陽性率で明らかな差はな かった。透析患者では, 正常対照群に比し未梢血 CD14 陽性単球の DR 抗原の発現量は有意に増加 していた（MFI 100 vs $111 ； \mathrm{p}<0.05) .1,25 \mathrm{D}_{3}$ 投 与前とパルス療法 3 日後で比較すると, この増加 した単球の DR 抗原の発現は有意に抑制された (MFI 111 $\rightarrow 96.7 ； \mathrm{p}<0.001)$. なお, 単球分画にお ける CD14 抗原の発現に関しては, パルス療法前 後でも明らかな変動は認めなかった（デー夕示さ ず).

3. パルス療法前後における好中球機能の変化

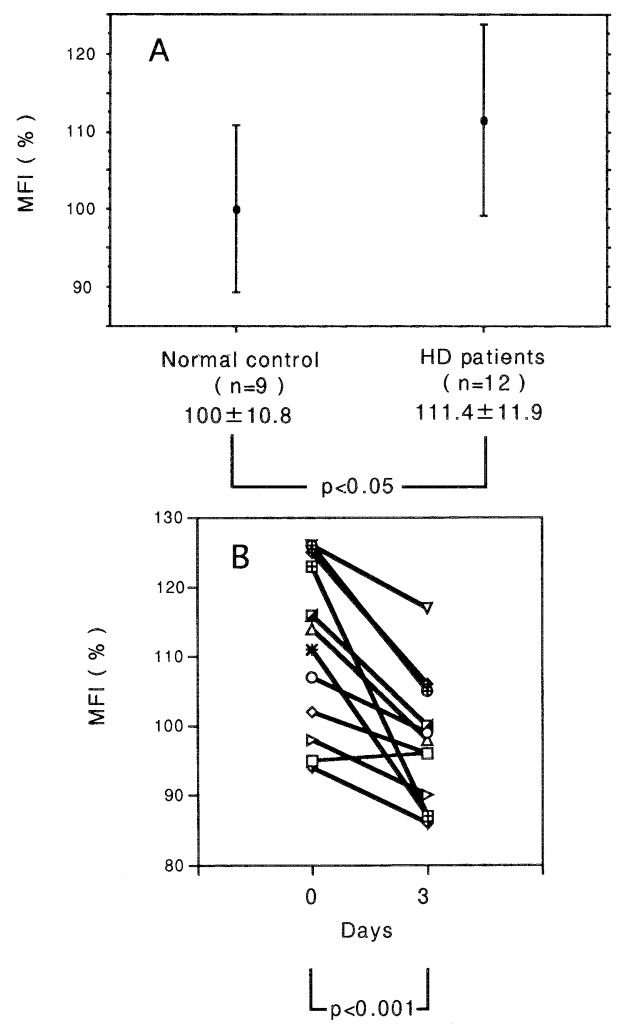

図 2 末梢血 CD14 陽性単球における HLA-DR 抗原の発現. 正常対照群と透析患者との比 較 $(\mathrm{A})$. 透析患者におけるパルス療法前後 での変化 $(B)$.

今回の検討では SOP の解析には透析施行直前 の全血を用いた。PMA 刺激後の好中球の SOP を，SOPによって生じた DCF の蛍光をフローサ イトメトリー法にて解析した。透析患者では好中 球の SOP は, 正常対照群に比し 2 倍近く有意に 高かった（MFI 100 vs $191.8 ； \mathrm{p}<0.001$ ). 1,25D 投与は, 好中球の SOP を増強する傾向を示した (図 3 ). 好中球の貫食能は低い傾向にあったが, $1,25 \mathrm{D}_{3}$ 投与は好中球の貪食能に対しては明らか な作用は示さなかった（図 4 )。

\section{考察}

$1,25 \mathrm{D}_{3}$ は $\mathrm{Ca}$ 代謝調節ホルモンとして古くから 知られている。近年, $1,25 \mathrm{D}_{3} レ$ レプターが，骨， 腸管，腎といった $\mathrm{Ca}$ 代謝に関わる組織の細胞の みならず， $\mathrm{Ca}$ 代謝と関係のない種々の細胞に発 現されていることが見出され， $1,25 \mathrm{D}_{3}$ が $\mathrm{Ca}$ 代謝 


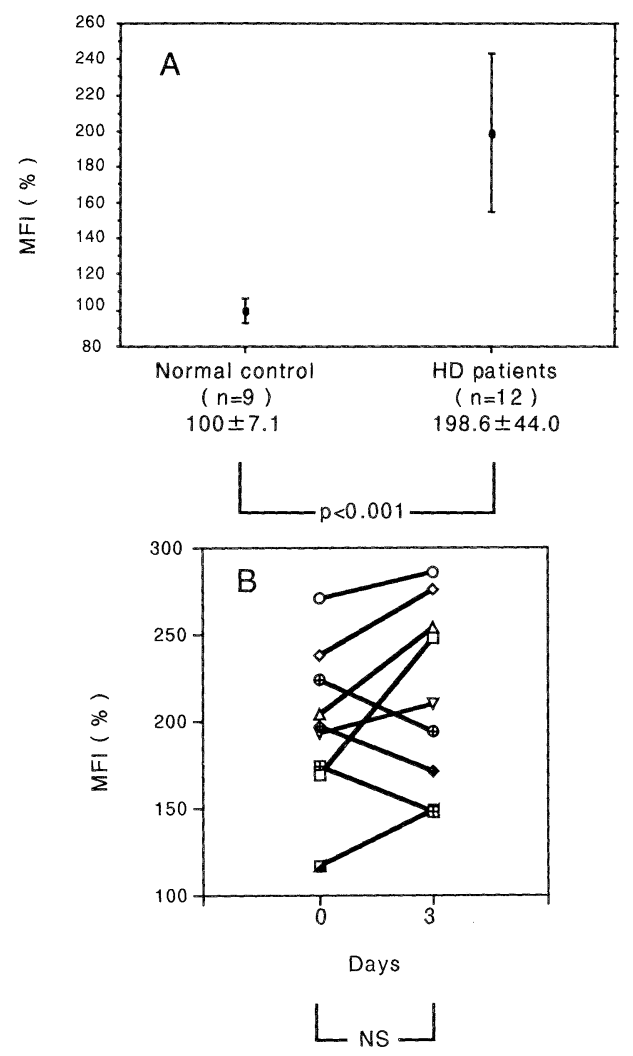

図 3 末梢血好中球に打ける活性酸素産生能. 正 常対照群と透析患者との比較 $(\mathrm{A})$ 。透析患 者に抢けるパルス療法前後での変化 $(\mathrm{B})$.

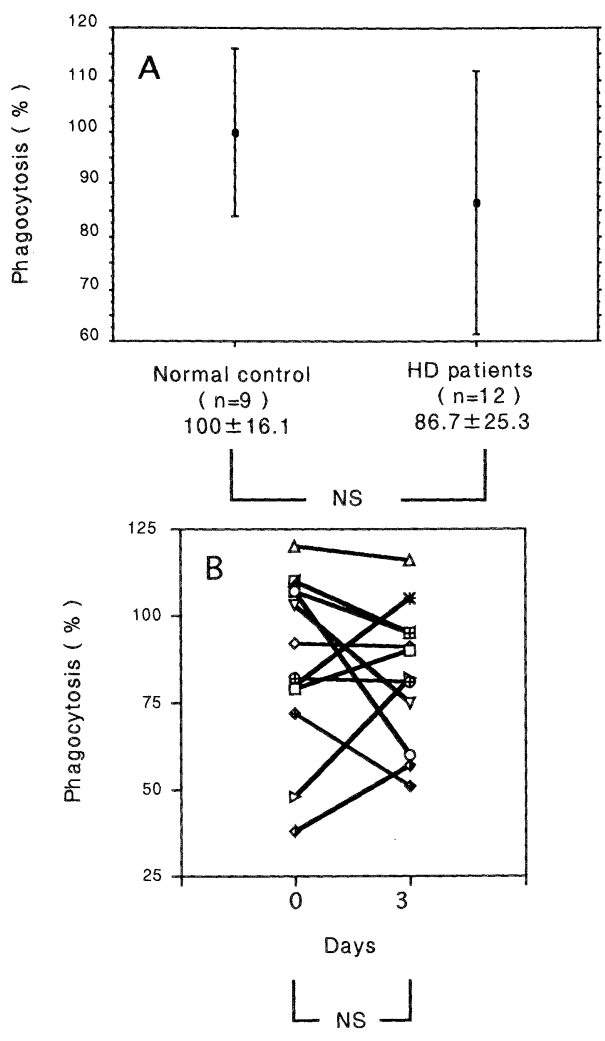

図 4 末梢血好中球の径 $2 \mu \mathrm{m}$ の carboxyl microsphere に対する貪食能。正常対 照群と透析患者との比較 $(\mathrm{A})$ 。透析患 者におけるパルス療法前後での変化 (B).

は難しい。維持透析患者における免疫異常に関し ては，とくに細胞性免疫の機能低下を指摘する報 告が多いが, 尿毒素, 代謝異常, 透析膜等の関与 が疑われている ${ }^{14)}$.しかしながら末期腎不全にお ける免疫異常へのビタミン $\mathrm{D}_{3}$ 欠乏状態の関与に ついての解析は十分ではない.

我々は，免疫応答における抗原提示に必要不可 欠である細胞表面上の class II 主要組織適合性 抗原の発現を， $1,25 \mathrm{D}_{3}$ が抑制することをラット甲 状腺上皮細胞，マウス精巣 Leydig 細胞，ヒト末 梢血単球において見出し，この $1,25 \mathrm{D}_{3}$ の class II 主要組織適合性抗原に対する抑制作用が，RNA ならびに蛋白レベルで認められること, プロスタ グランジン $\mathrm{E}_{2}$ の産生を介さないこと,さらには この作用発現が濃度依存性で $1,25 \mathrm{D}_{3}$ レセプター 
を介する作用であることを報告している ${ }^{8,15)}$. ヒト 単球においては in vitro では $0.01 〜 0.1 \mathrm{nM}$ のレ ベルから DR 抗原の発現抑制が認められ（データ 示さず)，これは正常の生理的血中 $1,25 \mathrm{D}_{3}$ 濃度レ ベルであることから, in vivoでも同様の効果が得 られる可能性が考えられた。今回の検討ではこれ らの in vitro のデー夕をふまえて $1,25 \mathrm{D}_{3}$ の in vivo の作用をパルス療法前後で検討した. 維持透 析患者の貪食細胞機能について, $1,25 \mathrm{D}_{3}$ パルス療 法前の $1,25 \mathrm{D}_{3}$ 欠乏状態では, 好中球の PMA 刺 激による SOD はフローサイトメトリー法でみる かぎり正常群に比し約 2 倍と有意に高かった $(\mathrm{p}<0.001)$. 透析患者における好中球の SOP に関 しては依然議論のあるところではあるが，概して 克進しているという報告が多い ${ }^{16,17)}$. SOP は種々 の刺激で誘導され，また SOP 測定法もさまざま である、今回の検討では，PMA 刺激後，DCFHDA の酸化により細胞内に生じた蛍光物質であ る DCF を測定して好中球の SOP を解析したが, 基礎疾患（糖尿病は除外）, 使用している透析膜, 各症例の病態等さまざまであるにもかかわらず， 透析患者では SOP 克進状態にあるという結果は 興味深い.

径 $2 \mu \mathrm{m}$ の calboxyl microsphere に対する好 中球の貪食能をみてみると有意差はないものの低 い傾向にあった。先天性ビタミン $\mathrm{D}_{3}$ 欠乏症であ るくる病に抢いては, 好中球貪食能の低下や呼吸 器における易感染性が，また実験的ビタミン $\mathrm{D}_{3}$ 欠乏マウスでは，マクロファージの貪食能や好中 球の遊走能が障害されることが報告されてい る ${ }^{2,3)}$. 未期腎不全における好中球の貪食能に関し ては低下しているという報告が多く尿毒症性物質 の蓄積等の原因が考えられているが,ビタミン $\mathrm{D}_{3}$ 欠乏状態の関与の可能性も今後検討の必要があ る.

単球の HLA-DR 抗原の発現量は正常に比し有 意に高かった $(\mathrm{p}<0.05)$. in vitro では $1,25 \mathrm{D}_{3} に$ 単球の HLA-DR 抗原の発現の抑制作用があるこ とよりやはりビタミン $\mathrm{D}_{3}$ 欠乏状態の関与の可能 性が考えられる。

今回の検討では, $1,25 \mathrm{D}_{3}$ パルス療法開始後の
$1,25 \mathrm{D}_{3}$ の血中濃度をみると, 1 回目の $5 \mu \mathrm{g}$ 経口 投与後 4 時間以内に $200 \mathrm{pg} / \mathrm{m} l(0.48 \mathrm{nM})$ を超え る十分な $1,25 \mathrm{D}_{3}$ 濃度が得られている.パルス療法 により直接影響をうける因子として PTH があ り，パルス療法後に血中 PTH レベルの低下が認 められたが, 今回検討しなかったが, PTH が貪食 細胞機能に影響を与えている可能性もある。 $1,25 \mathrm{D}_{3}$ 投与 3 日後でみてみると, 好中球の $\mathrm{SOP}$ は増強する傾向を示した。このことは，透析患者 における SOP 元進状態が $1,25 \mathrm{D}_{3}$ 欠乏状態による ものではないこと, $1,25 \mathrm{D}_{3}$ には諸家の報告のごと くSOP に対し増強作用のある可能性を示唆す る。領食能に関しては明らかな作用は認めなかっ た. Venezio ら ${ }^{18}$ は, 維持透析患者に対し, $1,25 \mathrm{D}_{3}$ の $0.25 \mu \mathrm{g} /$ 日の 6 週間の経口投与を行い, 好中球 ならびに単球における遊走能が有意に改善される ことを報告している。

$1,25 \mathrm{D}_{3}$ パルス療法前後で, 単球の DR 抗原の発 現は有意に抑制された $(\mathrm{p}<0.001)$. 背景がさまざ まであるにもかかわらず，今回の検討では，正常 群に比し単球の DR 抗原の発現は有意に高く, こ れが $1,25 \mathrm{D}_{3}$ 投与後に有意に抑制されることは, $1,25 \mathrm{D}_{3}$ が単球の $\mathrm{DR}$ 抗原の発現の制御に関わつ ていることを強く示唆し, $1,25 \mathrm{D}_{3}$ の in vitro の デー夕を裏づけるものであった.今回 $1,25 \mathrm{D}_{3}$ パル ス療法 3 日後で検討したが， 2 日後，4 日後でも 単球の DR 抗原の発現は有意に抑制される（デー 夕示さず)。単球の DR 抗原の発現は $\mathrm{CD} 4$ ヘル パーT細胞の抗原認識に必要不可欠で，この発現 量の低下は抗原呈示能の抑制をもたらすと考えら れるが生体内に打ける意義に関しては依然として 不明である。単球マクロファージ系の細胞の貪食 能に関しては今回検討しなかったが，in vitroに おいて $1,25 \mathrm{D}_{3}$ はこれを増強することから in vivo での効果は現在解析中である.

今回 $1,25 \mathrm{D}_{3}$ パルス療法前後で貪食細胞機能を 検討したが, 症例数は少ないものの $1,25 \mathrm{D}_{3}$ がこれ らの機能に影響を与えうることがはじめて明らか になった。 $1,25 \mathrm{D}_{3}$ の少量の補充療法による影響に ついては検討していないが，今後の解析が待たれ る。このような解析の報告は少なく, $1,25 \mathrm{D}_{3}$ の生 
体防御機構への関わり，末期腎不全における $1,25 \mathrm{D}_{3}$ 欠乏状態の骨代謝のみならず他の病態と の関わりについての解析の重要性が示唆された。

\section{結論}

維持透析における活性型ビタミン $\mathrm{D}_{3}$ パルス療 法前後で頜食細胞機能について検討した. ビタミ ン $\mathrm{D}_{3}$ 製剤の 3 週間以上の休薬後活性型ビタミン $\mathrm{D}_{3}$ の血中濃度は, パルス療法前は未検出レベルと 低かった. 維持透析患者 12 名においては, 正常対 照群に比し $\mathrm{CD}_{14}{ }^{+}$単球の DR 抗原の発現量なら びに好中球の PMA 刺激による活性酸素産生能 は有意に高かったが，好中球の貪食能は低い傾向 にあった。活性型ビタミン $\mathrm{D}_{3} 5 \mu \mathrm{g}$ 経口投与後は 4 時間以内に $200 \mathrm{pg} / \mathrm{m} l$ を超え, 投与 3 日後では 単球の DR 抗原の発現量は有意に抑制され, また 好中球の SOP は増強される傾向を示した. しか し好中球の貣食能には明らかな作用は認めなかっ た.

$1,25 \mathrm{D}_{3}$ が生体防御機構に対しても何らかの役 割を果たしており, 腎不全に打ける免疫不全状態 に関与している可能性が示唆された。

本論文の要旨は第 39 回日本透析医学会総会にて 発表した。

\section{文献}

1) Miller TE, Stewart E : Host immune status in uremia. I. Cell mediated immune mechanisms. Clin Exp Immunol 41 : 115-122, 1980

2) Stroder $J$ : Immunity in vitamin $D$ deficient rickets. In "Vitamin D and problems related to uremic bone disease." ed Norman AW, Schaefer K, Grigoleit H-G, von Herrath D, Ritz E, Berlin, Walter de Gruyter, p 675, 1975

3) Gavison R, Bar-Shavit $Z$ : Impaired macrophage activation in vitamin $D_{3}$ deficiency: differential in vitro effects of 1,25-dihydroxyvitamin $\mathrm{D}_{3}$ on mouse peritoneal macrophage functions. J Immunol 143 : 3686-3690, 1989

4) Provvendini DM, Tsuoka CD, Deftos LJ, Manolagas SC : $1 \alpha, 25$-Dihydroxyvitamin $\mathrm{D}_{3}$ -binding macromolecules in human $B$ lymphocytes: Effects on immunogloblin production. J Immunol 136 : 2734-2740, 1986

5) Rigby WFC, Denome S, Fanger MW : Regulation of lymphokine production and human T lymphocyte activation by 1,25-dihydroxyvitamin $\mathrm{D}_{3}$. J Clin Invest 79 : 1659-1664, 1987

6) Reichek H, Koeffler HP, Tobler A, Norman $\mathrm{AW}: 1 \alpha$, 25-Dihydroxyvitamin $\mathrm{D}_{3}$ inhibits $\gamma$-interferon synthesis by normal human peripheral blood lymphocytes. Proc Natl Acad Sci USA 84 : 3385-3389, 1987

7) Tobler A, Miller C, Norman AW, Koeffler HP : 1,25-Dihydroxyvitamin $\mathrm{D}_{3}$ modulates the expression of a lymphokine (granulocytemacrophage colony-stimulating factor) posttranscriptionally. J Clin Invest 81 : 1819-1823, 1988

8) Tokuda N, Mizuki N, Kasahara M, Levy $\mathrm{RB}:$ 1,25-dihydroxyvitamin $\mathrm{D}_{3}$ down-regulation of HLA-DR on human peripheral blood monocytes. Immunology 75 : 349-354, 1992

9) Bass DA, Parce JW, Dechatelet LR, Szejda P, Seeds MC, Thomas M: Flow cytometric studies of oxidative product formation by neutrophils: A graded response to membrane stimulation. J Immunol 130 : 1910-1917, 1983

10) Griffin JD, Ritz J, Nadler LM, Schlossman $\mathrm{SF}$ : Expression of myeloid differentiation antigens on normal and malignant myeloid cells. J Clin Invest 68 : 932-941, 1981

11) Reicher H, Koeffler HP, Norman AW : The role of the vitamin $\mathrm{D}$ endocrine system in health and disease. N Engl J Med 320 : 980981, 1989

12) $\mathrm{Xu} \mathrm{H}$, Soruri A, Gieseler RKH, Peters JH : 1,25-dihydroxyvitamin $\mathrm{D}_{3}$ exerts opposing effects to IL-4 on MHC class-II antigen expression, accessory activity, and phagocytosis of human monocytes. Scand J Immonol 38:535-540, 1993

13) Cohen MS, Mesler DE, Snipes RG, Gray TK : 1,25-dihydroxyvitamin $\mathrm{D}_{3}$ activates secretion of hydrogen peroxide by human monocytes. J Immunol 136 : 1049-1053, 1986

14) Descamps-Latscha $B:$ The immune system 
in end-stage renal disease. Curr Opin Nephrol Hypertens 2:883-891, 1993

15) Tokuda N, Mano T, Levy RB : 1,25-dihydroxyvitamin $\mathrm{D}_{3}$ antagonizes interferongamma-induced expression of class II major histocompatibility antigens on epithelial and interstitial cells. Endocrinology 127 : 14191427, 1990

16）上田雄一郎：透析患者における食細胞の活性酸 素放出能の検討. 感染症学雑誌 63：997-1006, 1989
17) Rhee MS, McGoldrick MD, Meuwissen HJ : Serum factor from patients with chronic renal failure enhances polymorphonuclear leukocyte oxidative metabolism. Nephron 42:6-13, 1986

18) Venezio FR, Kozeny GA, DiVincenzo CA, Hano J : Effect of 1,25 dihydroxyvitamin $\mathrm{D}_{3}$ on leukocyte function in patients receiving chronic hemodialysis. J Infect Dis 158 : 11021105, 1988 